\title{
Bioaccumulation of organochlorine pesticides (OCPs) in molluscs and fish at the Sai Gon - Dong Nai estuary
}

\author{
Tích lũy sinh học hóa chất bảo vệ thực vật clo hưu co trong nhuyễn thể và cá \\ tại cứa sông Sài Gòn - Đồng Nai \\ Research article
}

Nguyen Xuan Tong ${ }^{1,2}$, Tran Thi Thu Huong ${ }^{3}$, Duong Thi Thuy ${ }^{1,4}$, Mai Huong ${ }^{5}$, Duong Trong Khang ${ }^{2}$, Huynh Cong Luc ${ }^{2}$, Pham Thi Loan ${ }^{2}$, Le Thi Phuong Quynh ${ }^{6}$

${ }^{I}$ Graduate University of Science and Technology, Viet Nam Academy of Science and Technology (VAST); ${ }^{2}$ Institute for Environmental Science, Engineering and Management, Industrial University of Ho Chi Minh City; ${ }^{3}$ Faculty of Environmental, Ha Noi University of Mining and Geology; ${ }^{4}$ Institute of Environmental Technology, VAST; ${ }^{5}$ University of Science and Technology of Ha Noi, VAST; ${ }^{6}$ Institute of Natural Product Chemistry, VAST, 18 Hoang Quoc Viet, Cau Giay, Ha Noi, Vietnam

\begin{abstract}
The aim of this study is to assess the biological accumulation of pesticide residues in aquatic organisms in Sai Gon - Dong Nai (SG-DN) estuary. Fish and mollusks were collected directly at the Soai Rap and Long Tau estuary of the SG-DN river system, washed and separated for taking the tissue. The organochlorine compounds from the tissue were then extracted and analyzed by gas chromatography system. The results showed that, the concentration of OCPs in Tegillarca granosa, Meretrix lyrata, Margaritifera auricularia and Bostrychus sinensis varied from 6.4 to $59.9 \mu \mathrm{g} / \mathrm{kg}, 7.2$ to $322 \mu \mathrm{g} / \mathrm{kg}, 4.5$ to $62.1 \mu \mathrm{g} / \mathrm{kg}$ and 2.9 to $114.3 \mu \mathrm{g} / \mathrm{kg}$ fresh weight, respectively. In general, molluscs species that accumulate more heptachlor, aldrin, endrin or dieldrin tend to accumulate less DDT (dichlorodiphenyltrichloroethane). Endosulfan was the most commonly found in three bivalve mollusks while DDTs (1.5-75.2 $\mu \mathrm{g} / \mathrm{kg}$, averaging $8.7 \mu \mathrm{g} / \mathrm{kg}$ weight) was the most popular OCPs in the fish (Bostrychus sinensis) samples. In DDT group, the p,p'-DDT metabolite accounted for the largest percentage, reaching $50 \%$ of total DDTs. In $\mathrm{HCH}$ (Hexachlorocyclohexane) group, $\beta-\mathrm{HCH}$ isomer was predominant in almost samples.
\end{abstract}

Mgr đích ccc nghiên cch này là đánh giá tích lũy sinh hhn ccn thuu trr sâu trong các sinh vvn ssnh dưuh nưuh ttu khu vvu ccu sông Sài Gòn - ĐĐn Nai (SG-DN). Cá và nhuyyu thh đưuy llù trry tiiy iicủa sông Soài RRà và Lòng Tàu thuu hh thhu sông SG-DN, đu-D ru-ss-D và tách llc phhh mô thht. Các hhc chh clo hho co sau đó đưư tách chii và phân tích bbch hh thhh ssh ký khí. Kết quả nghiên cưu cho thấy, du luọng OCPs tích tụ trong sò điệp (Tegillarca granosa), ngao (Meretrix lyrata), trai nước ngọt (Margaritifera auricularia) và cá bóp (Bostrychus sinensis) dao động tuoong ưng tù 6,4 đến 59,9 $\mu \mathrm{g} / \mathrm{kg}$, 7,2 đến $322 \mu \mathrm{g} / \mathrm{kg}, 4,5$ đến $62,1 \mu \mathrm{g} / \mathrm{kg}$ và 2,9 đến 114,3 $\mu \mathrm{g} / \mathrm{kg}$ trọng luợng tươi. Nhìn chung, loài nhuyễn thể nào tích lũy nhiều heptachlor, aldrin, endrin hoăc dieldrin có xu huoóng tích lũy it DDT (Dichlorodiphenyltrichloroethane). Endosunfan là nhóm thuốc được tìm thấy nhiều nhất trong các loài nhuyễn thể nghiên cưu. Ngược lại, nhóm DDT lại phổ biến ở cá Bostrychus sinensis (1.5-75.2 $\mu \mathrm{g} / \mathrm{kg}$, trung bình $8.7 \mu \mathrm{g} / \mathrm{kg}$ trọng luợng). Dạng p.p'-DDT trong nhóm DDT chiếm tỷ lệ cao nhất, tới $50 \%$ DDT tổng. Trong khi đó, đồng dạng $\beta$-HCH của nhóm HCH (Hexachlorocyclohexane) chiếm đa số trong hầu hết các mẫu.

Keywords: biological accumulation, estuarine, fish, molluscs, pesticide 


\section{Introduction}

The Sai Gon - Don Nai (SG-DN) River system with a large estuarine area is the main water sources for agriculture and the daily activities of people living along the river banks in Ho Chi Minh City and the neighbouring provinces (Ba Ria Vung Tau, Dong Nai, Long An and Binh Duong). However, rapid development in this region raised concerns about local environment and ecological integrity (Anh, 2003; Nguyen et al, 2007). Large amounts of untreated municipal and industrial wastewater, as well as runoff from landfills carrying numerous toxic complex contaminants are released directly into the river. The increase in population and productive activities, as well as use of pesticides without logical in agricultural production increased pesticide residues in the river. Since many years, this estuary has been served as one of the main areas for large-scale aquaculture. Many species of fishes and molluses such as oysters, clam etc. were cultivated in here. These species have a long growing cycle, ranging from 8 to 10 months and need to live in a clean environment without contamination. Therefore, the protection of river water quality is an important task for sustainable development, especially when demand for water supply and use of fishery products increases rapidly.

Organochlorine pesticides (OCPs) which are large groups of crop protection chemicals have been widely used for various applications during the past several decades. Due to their persistent, semi-volatile, toxic properties and highly bio-accumulation especially in lipophilic substances and tissues, organochlorines distribute ubiquitously in the global environment and can be detected at all levels of food chains, including humans. Many OCPs are classified into persistent organic pollutants (POPs), according to Stockholm formula (UNEP, 2011). These compounds affect seriously public health of humans and wildlife because they alter normal functions of endocrine (endocrine disrupter pesticides) (Mnif et al, 2011), interfere with female hormonal function, leading to negative effects on the reproductive systems (Bretveld et al, 2006), have the close relationship with neurodegeneration diseases (Dana, 2008), many popular cancers such as breast cancer (Wolff et al, 2007; Bhatnagar et al, 2002), non Hodgkin's lymphoma (Cantor et al, 1992), and other types of cancer (Alavanja et al 2013).

Although the use of many organochlorine compounds such as Lindane, DDT, Endrin, Dieldrin etc. has been prohibited according to Circular No. 21/2013/MARD because of the long half-life and difficulty for controlling persistent residue (MARD, 2013). However, pesticide contamination still occurs and is difficult to handle, including the issue of OCPs bioaccumulation in the environment. Some reports published recently focus on the assessment of OCPs and heavy metal pollution in sediments, rivers, seas and estuaries along Vietnam such as: Mekong River Delta (Nguyen et al, 2006), Sai Gon - Dong Nai River (Nguyen et al, 2007), Tien estuary (Nguyen et al, 2017), Thi Vai Estuary and Can Gio Mangrove Forest (Costa-Böddeker, 2016), Nha Trang Bay (Hoang et al, 2015), Red River Delta and along the coast of North Vietnam (Dang et al, 1998). Until now, there is a few of studies investigating the toxic OCPs bioaccumulation in Tegillarca granosa, Meretrix lyrata,
Margaritifera auricularia and Bostrychus sinensis cultured in the SG-DN estuary. Therefore, the aim of this work is to investigate levels of OCPs residues and their isomer including of the groups such as: HCHs, DDTs, Aldrin, Dieldrin, Heptachlor, Endosulfans in these species in SG-DN estuary area.

\section{Material and methods}

\subsection{Study area}

The current study was conducted in the Long Tau and Soai Rap estuary belonging to the Sai Gon-Dong Nai estuary, located in Ho Chi Minh city, Vietnam (Figure 1). The estuary with funnel shape has a total catchment area of $43,500 \mathrm{~km}^{2}$, including areas contiguous with the Ba Ria Vung Tau, Dong Nai, Long An and Binh Duong provinces. The river catchment has two distinct seasons: the dry season is from December to April and the rainy season is from May to November, with total annual rainfall from 170.8 $212.4 \mathrm{~mm}$. There are four main rivers (Soai Rap, Long Tau, Thi Vai and Cai Mep) collective adding water to the SGDN River system, before coming to the East Sea with the total annual discharge of approximately 34 billion $\mathrm{m}^{3}$ (Le et al, 2015). Currently, the area of the paddy field in the catchment of the SG-DN river system is around 18,000 hectares.

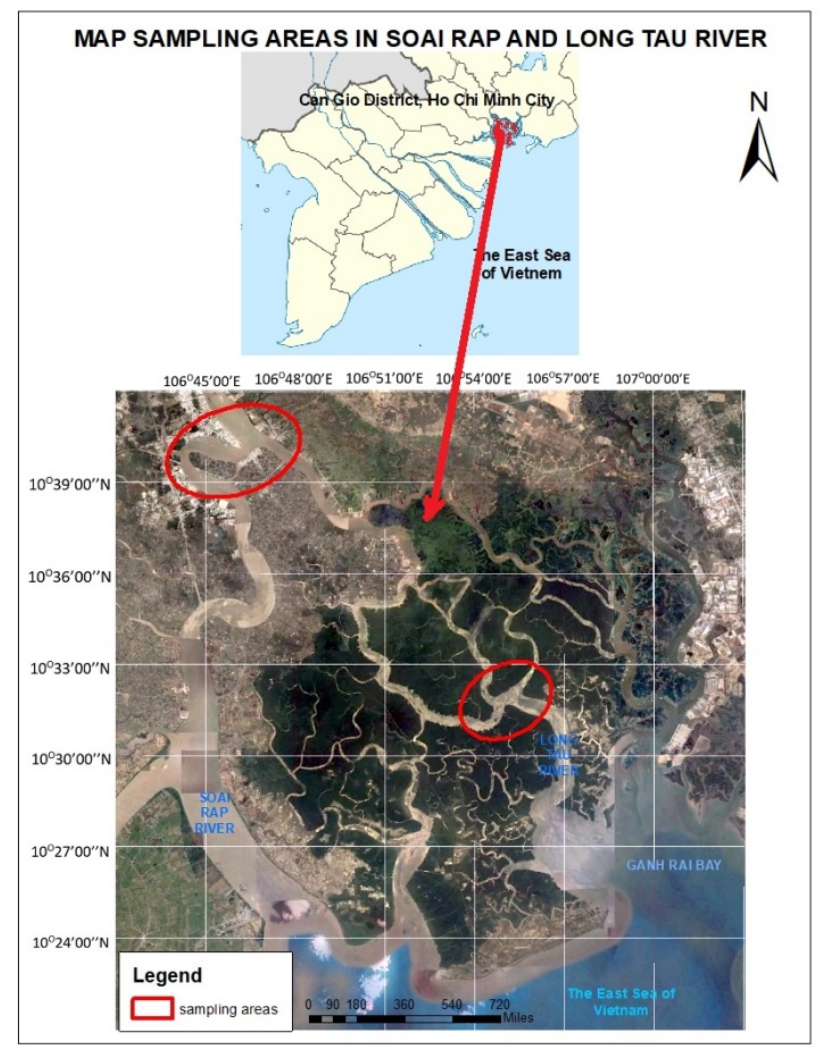

Figure 1. The SG-DN estuary and sampling areas

\subsection{Sampling}

\subsubsection{Sample identification}

For sample identification, all the samples are classified according to their morphological characteristics and explicit enumeration to the David's category (1969): scallops, 
clams, mussel and fish. The bivalve molluscs (clams, oysters and clams) are brushed with a brush, washed with water to remove the adhering detritus.

\subsubsection{Sampling}

Thirty-eight sites surrounding the boundary of the Long Tau and Soai Rap estuary belong to the SG-DN system were selected for the current study (Figure 1). Samplings were conducted in two seasons (rainy season: May 2017, dry season: October and November 2017). The sampling process is similar to the procedure of two authors Kožul (2008) and Mohamed (2012). The experimental samples including: scallops, mussel, clams and fish were taken directly and randomly by hand. All the sample were immediately kept in plastic boxes and stored in an ice-chest at $5^{0} \mathrm{C}$ and transported to the laboratory for analysis. The group of bivalve molluscs was weighed, classified, peeled off the shells to collect the meat. Their tissues were homogenized and stored in the dark glass bottles at $-5^{\circ} \mathrm{C}$ for further analysis (Kožul et al, 2008; Shreadah et al, 2012).

\subsection{Procedure for sample treatment and analysis}

The processing analysis is followed the steps presented in the Figure 2 (Kožul, 2008; Shreadah, 2012).

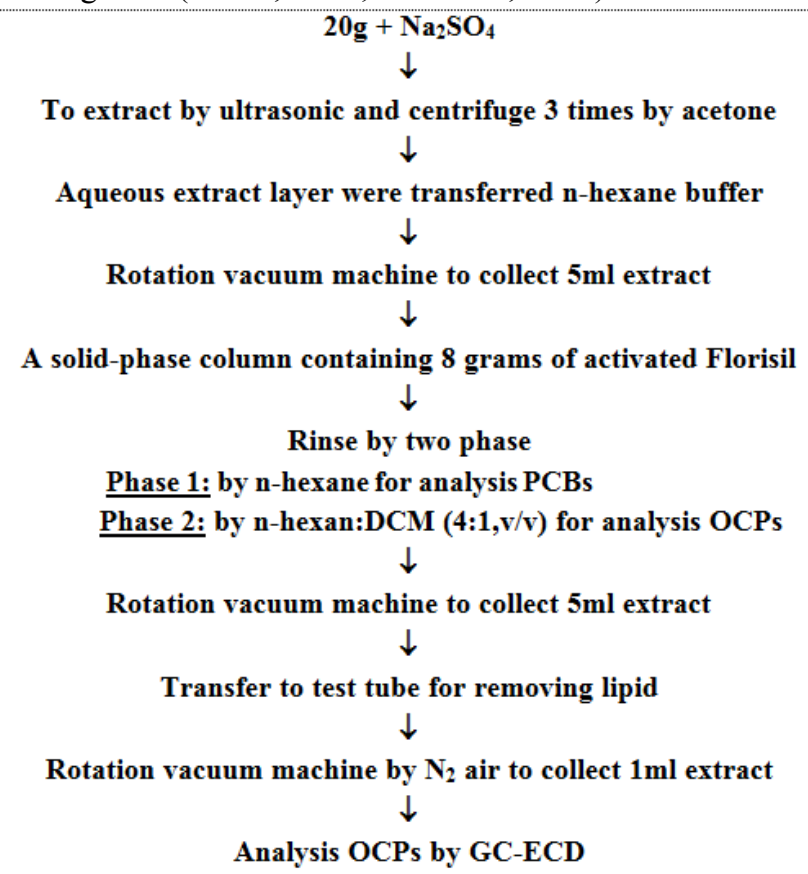

Figure 2. The procedure for analyzing OCPs in experimental samples

\subsection{Statistical analysis}

All experiments were done in triplicate and the data were calculated as mean \pm SD (standard deviation) and drawn by the software SigmaPlot. Statistical significance was accepted at a level of $\mathrm{p}<0.05$.

\section{Results and discussion}

\subsection{The analysis results of OCPs component}

In this study, the individual numbers of the analysed species M. auricularia, T. granosa, M. lyrata and B. sinensis were $8,9,13$ and 8 , respectively. Table 1 shows the average mean (mean), the standard error of the mean (SEM) and the varied values of OCPs in all analysed samples. According to Vietnamese standard, 12 different common components of OCPs and pesticides residues were detected with highcontents in the both three bivalve molluscs and fish $B$. sinensis species collected in the study area (MARD, 2013 ; 2015). The bioaccumulation of OCPs in the survey species is significantly different. Almost all individuals of Bostrychus sinensis did not accumulate endosulfan II; many individuals of Tegillarca granosa did not accumulate $\alpha-\mathrm{HCH}$ and $\delta-\mathrm{HCH}$; Meretrix lyrata individuals did not accumulate aldrin, sulphate endosulfan and Margaritifera auricularia did not accumulate aldrin.

The highest total OCP accumulation in M. lyrata was $114.317 \mu \mathrm{g} / \mathrm{kg}$, while the lowest in M. auricularia varied from 4.472 to $62.114 \mu \mathrm{g} / \mathrm{kg}$ by wet weight. The analysis results showed that the highest total OCP accumulation in Meretrix lyrata was $114,317 \mu \mathrm{g} / \mathrm{kg}$, while the lowest in Margaritifera auricularia varied from 4,472 to $62,114 \mu \mathrm{g}$ $\mathrm{kg}$ by wet weight. However, the endosulfan group was found in all three bivalve molluscs with the content of 1.5 - $75.2 \mu \mathrm{g} / \mathrm{kg}$ and the DDT group was the most common OCPs in the fish $B$. sinensis with the content of $8.7 \mu \mathrm{g} / \mathrm{kg}$ by wet weight. The high accumulation of $\mathrm{HCHs}$ in fish sample indicated the pollution in the environment and the risk to human health.

Table 1. Organochlorine pesticides detected $(\mu \mathrm{g} / \mathrm{kg})$ in all sample

\begin{tabular}{ccccc}
$\begin{array}{c}\text { Species } \\
\text { Sample size }\end{array}$ & $\begin{array}{c}\text { Margaritifera auricularia } \\
(\mathbf{N}=\mathbf{8})\end{array}$ & $\begin{array}{c}\text { Tegillarca granosa } \\
(\mathbf{N}=\mathbf{1 3})\end{array}$ & $\begin{array}{c}\text { Meretrix lyrata } \\
(\mathbf{N}=\mathbf{9})\end{array}$ & $\begin{array}{c}\text { Bostrychus sinensis } \\
(\mathbf{N}=\mathbf{8})\end{array}$ \\
\hline Total HCHs & $\mathbf{6 . 5 2 7}$ & $\mathbf{5 . 0 0 5}$ & $\mathbf{7 . 1 6 0}$ & $\mathbf{4 . 9 3 9}$ \\
SEM & 1.914 & 0.925 & 4.344 & 1.509 \\
Range & $2.001-16.591$ & $1.706-12.149$ & $1.742-41.832$ & $0.804-13.788$ \\
$\alpha$-HCH & $\mathbf{1 . 7 5 9}$ & $\mathbf{0 . 7 1 7}$ & $\mathbf{1 . 5 1 5}$ & $\mathbf{0 . 9 7 0}$ \\
SEM & 0.492 & 0.288 & 0.905 & 0.367 \\
Range & $0.745-4.128$ & $0-3.695$ & $0-8.695$ & $0-3.132$
\end{tabular}




\begin{tabular}{|c|c|c|c|c|}
\hline $\begin{array}{c}\text { Species } \\
\text { Sample size }\end{array}$ & $\begin{array}{c}\text { Margaritifera auricularia } \\
\qquad(\mathrm{N}=\mathbf{8})\end{array}$ & $\begin{array}{c}\text { Tegillarca granosa } \\
\qquad(\mathrm{N}=13)\end{array}$ & $\begin{array}{l}\text { Meretrix lyrata } \\
\qquad(\mathbf{N}=9)\end{array}$ & $\begin{array}{c}\text { Bostrychus sinensis } \\
(\mathbf{N}=\mathbf{8})\end{array}$ \\
\hline$\beta-\mathrm{HCH}$ & 3.107 & 2.076 & 3.330 & 2.246 \\
\hline SEM & 1.098 & 0.482 & 2.058 & 0.783 \\
\hline Range & $0.817-10.012$ & $0-6.455$ & $0.586-19.704$ & $0.221-5.458$ \\
\hline$\delta-\mathrm{HCH}$ & 0.686 & 0.889 & 0.389 & 1.224 \\
\hline SEM & 0.313 & 0.445 & 0.195 & 0.483 \\
\hline Range & $0-2.502$ & $0-4.702$ & $0-1.587$ & $0-3.961$ \\
\hline$\gamma-\mathrm{HCH}$ & 0.976 & 1.323 & 1.925 & 0.500 \\
\hline SEM & 0.245 & 0.392 & 1.247 & 0.199 \\
\hline Range & $0.429-2.102$ & $0-3.922$ & $0.182-11.845$ & $0-1.707$ \\
\hline Total DDTs & 8.240 & 6.083 & 6.801 & 16.662 \\
\hline SEM & 2.432 & 1.673 & 2.455 & 8.749 \\
\hline Range & $0.542-17.729$ & $1.038-20.094$ & $2.030-24.475$ & $1.532-75.224$ \\
\hline$p, p^{\prime}$-DDE & 1.060 & 1.075 & 0.991 & 2.084 \\
\hline SEM & 0.525 & 0.394 & 0.475 & 0.683 \\
\hline Range & $0-4.094$ & $0-4.721$ & $0-4.419$ & $0-4.596$ \\
\hline$p, p^{\prime}-\mathrm{DDD}$ & 4.560 & 3.107 & 1.899 & 4.245 \\
\hline SEM & 1.752 & 1.058 & 0.851 & 1.613 \\
\hline Range & $0.001-10.856$ & $0.109-12.746$ & $0-8.350$ & $0.564-12.603$ \\
\hline$p, p^{\prime}-\mathrm{DDT}$ & 2.620 & 1.942 & 3.910 & 10.333 \\
\hline SEM & 0.81 & 0.653 & 1.175 & 7.417 \\
\hline Range & $0.442-6.640$ & $0-9.017$ & $1.336-11.706$ & $0.464-61.944$ \\
\hline $\begin{array}{l}\text { Total endosul- } \\
\text { fans }\end{array}$ & 4.591 & 14.482 & 27.831 & 9.674 \\
\hline SEM & 1.188 & 2.952 & 24.02 & 15.836 \\
\hline Range & $0.534-9.862$ & $0.813-30.615$ & $0.205-219.491$ & $0-47.061$ \\
\hline Endosulfan I & 2.405 & 1.415 & 1.059 & 1.737 \\
\hline SEM & 1.199 & 0.661 & 0.454 & 0.7 \\
\hline Range & $0-8.854$ & $0-8.075$ & $0.118-3.537$ & $0-5.682$ \\
\hline Endosulfan II & 0.456 & 2.620 & 0.531 & 0.164 \\
\hline SEM & 0.13 & 0.962 & 0.164 & 0.109 \\
\hline Range & $0-1.143$ & $0.639-13.460$ & $0-1.409$ & $0-0.765$ \\
\hline $\begin{array}{l}\text { Endosulfan Sul- } \\
\text { fat }\end{array}$ & 1.730 & 10.446 & 26.241 & 7.772 \\
\hline SEM & 0.868 & 3.098 & 23.707 & 5.637 \\
\hline Range & $0.105-5.743$ & $0-29.679$ & $0-215.414$ & $0-46.507$ \\
\hline Total OCPs & 28.020 & 36.992 & $\mathbf{5 1 . 5 8 5}$ & 35.750 \\
\hline SEM & 7.105 & 4.488 & 34.026 & 13.326 \\
\hline Range & $4.472-62.114$ & $6.360-59.897$ & $7.181-321.996$ & $2.925-114.317$ \\
\hline Heptachlor & 1.360 & 3.516 & 7.738 & 1.003 \\
\hline SEM & 0.315 & 0.755 & 3.853 & 0.256 \\
\hline Range & $0.178-2.917$ & $0-8.121$ & $0-30.524$ & $0-2.056$ \\
\hline Aldrin & 1.002 & 1.713 & 0.458 & 1.245 \\
\hline SEM & 0.547 & 0.474 & 0.337 & 0.43 \\
\hline Range & $0-4.380$ & $0-5.421$ & $0-3.055$ & $0-3.815$ \\
\hline Dieldrin & 4.626 & 2.793 & 0.201 & 1.743 \\
\hline SEM & 3.441 & 1.756 & 0.074 & 0.564 \\
\hline Range & $0.055-27.816$ & $0-23.157$ & $0-0.557$ & $0-3.822$ \\
\hline Endrin & 1.675 & 3.359 & 1.936 & 0.589 \\
\hline SEM & 1.252 & 1.317 & 0.916 & 0.217 \\
\hline Range & $0.039-10.391$ & $0-17.351$ & $0-8.341$ & $0-1.580$ \\
\hline
\end{tabular}

* SEM: Standard error of the mean

\subsection{The analysis results of the organochlorine derivative groups}

Figure 3 illustrates the content of seven types of pesticides affecting 4 studied species: $M$. auricularia, $T$. granosa, $M$. lyrata, and $B$. sinensis. In general, it can be seen that endosunfans were the most predominant compounds in three molluscs species; followed by DDT, $\mathrm{HCH}$, heptachlor and the rest substances. However, the content of substances high or low is very different in different species. The contents of endosunfans in M. lyrata, T. granosa, B. sinesis and $M$. auricularia respectively were $27,831 \mu \mathrm{g} / \mathrm{kg}, 14,482$ $\mu \mathrm{g} / \mathrm{kg}, 9,674 \mu \mathrm{g} / \mathrm{kg}$ and $4,591 \mu \mathrm{g} / \mathrm{kg}$, respectively. Followed by the content of DDT was $6,083 \mu \mathrm{g} / \mathrm{kg}$ in $T$. granosa and the lowest content in this species is the $\mathrm{HCH}$ group. In contrast, in fish $B$. sinensis, DDTs were the most predominant OCPs $(16,662 \mu \mathrm{g} / \mathrm{kg})$, followed by endosunfans and $\mathrm{HCH}$ derivatives. However, in M. lyrata, heptachlor had the relatively equal amount to HCHs and DDTs. 


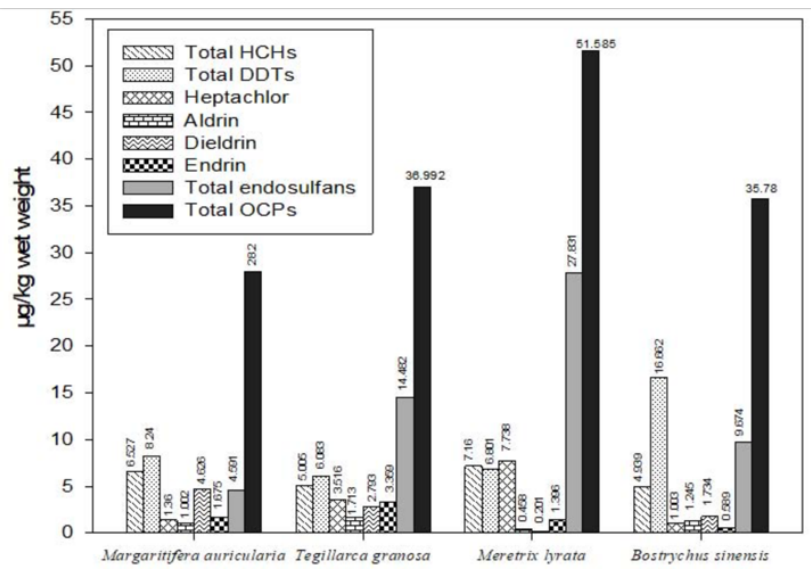

Figure 3. Total OCPs and organochlorine groups in the samples

Figure 4 shows contents $(\mu \mathrm{g} / \mathrm{kg})$ of five $\mathrm{HCH}$ derivatives determined in the study species. The highest bioaccumulation of total HCHs was observed in M. lyrata $(7,159$ $\mu \mathrm{g} / \mathrm{kg}$ ), followed by $M$. auricularia $(6.528 \mu \mathrm{g} / \mathrm{kg}), B$. sinensis $(5,94 \mu \mathrm{g} / \mathrm{kg})$ and the lowest value of $5 \mu \mathrm{g} / \mathrm{kg}$ for T. granosa. In this group, $\beta-\mathrm{HCH} \mathrm{d}$ accounted for more than $45.5 \%$ of all $\mathrm{HCH}$ found in the survey species. It is interesting to note that $M$. auricularia and $M$. lyrata contained the similar content of $\beta-\mathrm{HCH}$ (about $3.33 \mu \mathrm{g} / \mathrm{kg}$ ), higher than B. sinensis $(2,246 \mu \mathrm{g} / \mathrm{kg})$ and T. granosa $(2.076$ $\mu \mathrm{g} / \mathrm{kg}$ ). Anh finally, the content of $\alpha-\mathrm{HCH}$ was the largest within HCHs group in M. auricularia $(1.759 \mu \mathrm{g} / \mathrm{kg})$, while $\gamma-\mathrm{HCH}$ was predominant in $M$. lyrata (nearly $2 \mu \mathrm{g} / \mathrm{kg}$ ), $\delta$ $\mathrm{HCH}$ in B. sinensis $(1.224 \mu \mathrm{g} / \mathrm{kg})$. This result is different from the previous report (Pham et al, 2011), in which $\mathrm{HCHs}$ were detected in fish samples collected in Minh Dai commune, $\mathrm{Phu}$ Tho province with concentrations varied from 12 to $78 \mathrm{ng} / \mathrm{g}$ wet weight and the average value was $31 \mathrm{ng} / \mathrm{g}$.

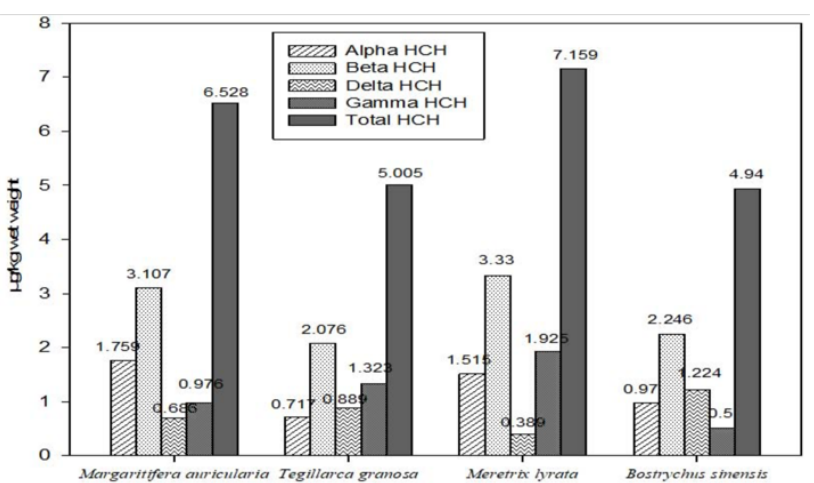

Figure 4. HCHs and compositions in the samples

Figure 5 illustrates the level of three DDT derivatives including p,p'-DDE, p,p'-DDD and p,p'-DDT observed in the study species. The highest bioaccumulation of DDTs total was observed in $B$. sinensis $(16,662 \mu \mathrm{g} / \mathrm{kg})$, followed by $M$. auricularia $(8.24 \mu \mathrm{g} / \mathrm{kg})$, M. lyrata $(6,8 \mu \mathrm{g} / \mathrm{kg})$, and the lowest value of only $6 \mu \mathrm{g} / \mathrm{kg}$ was in $T$. granosa. In general, the content of p,p'-DDT metabolite accounted for the largest percentage, reaching $50 \%$ of DDTs total in all samples. In particular, the ratio $\mathrm{p}, \mathrm{p}$ '-DDT/DDTs of $B$. sinensis was highest (62\%), followed by $M$. lyrata (57\%). In contrast, p,p'-DDD was more predomidant in Margaritifera auricularia and Tegillarca granosa, accounting for to $50 \%$ of DDTs total. This indicates the high stability of the stock compounds ( $p, p^{\prime}-D D T$ and $\mathrm{p}, \mathrm{p}$-DDD) in the aquatic environment compared with other metabolites.

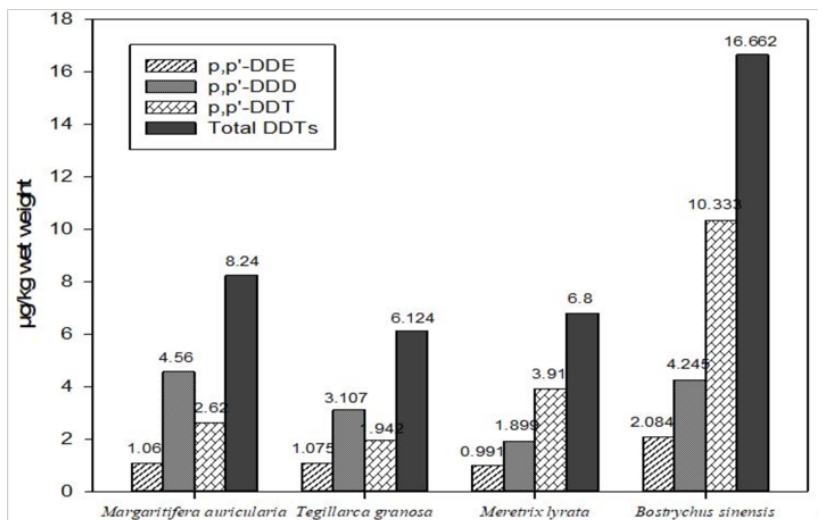

Figure 5. DDTs and compositions in the samples

Figure 6 shows the levels of endosulfans total and the form of derivatives in 4 studied species. The highest bioaccumulation of endosulfan total was observed in $M$. lyrata (up to $27.831 \mu \mathrm{g} / \mathrm{kg})$, followed by $T$. granosa $(14,481 \mu \mathrm{g} / \mathrm{kg}), B$. sinensis $(9,673 \mu \mathrm{g} / \mathrm{kg})$ and the lowest value of only 4.591 $\mu \mathrm{g} / \mathrm{kg}$ was in $M$. auricularia. In figure 5, except $M$. auricularia samples, endosulfan sulphate tended to be more active than other endosulfan derivatives in the remaining three species. It accounted for the largest percentage, reaching up to $80-90 \%$ of endosulfans total and this value in $M$. lyrata $(26,241 \mu \mathrm{g} / \mathrm{kg}), T$. granosa $(10,441 \mu \mathrm{g} / \mathrm{kg})$ and B. sinensis is $7,772 \mu \mathrm{g} / \mathrm{kg}$, respectively. For $M$. auricularia, total endosulfans was slightly lower than endosulfan I, this value is $1.73 \mu \mathrm{g} / \mathrm{kg}$ ) compared with $2.4 \mu \mathrm{g} / \mathrm{kg}$ endosulfan I. According to Dang et al (2001), in the canals in Hanoi city, p,p'DDE always accounts for the largest proportion, up to 70$80 \%$ of DDT in freshwater mussel (Angulyagra sp.).

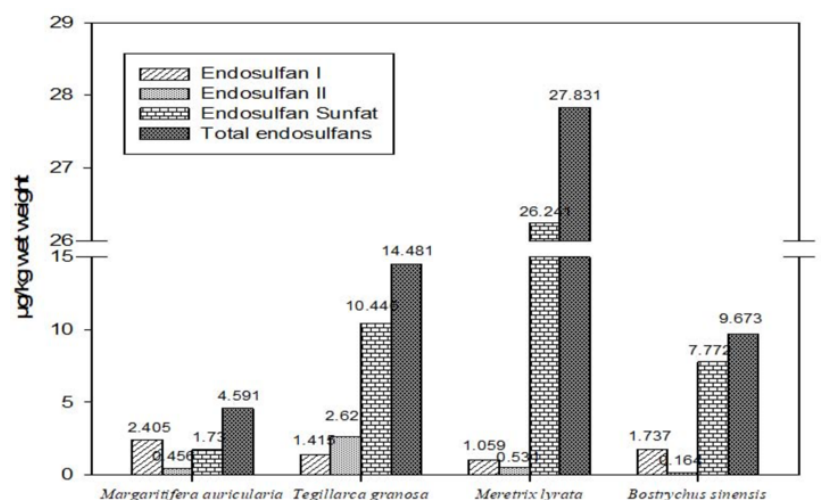

Figure 6. Endosulfans and compositions in the samples

The study of bioaccumulation OCPs in some species of bivalve molluscs and fish in the SG-DN estuary showed that there was a difference in the level of bioaccumulation in each species. In general, molluscs species tended to accumulate heptachlor, aldrin, endrin or dieldrin more than DDTs. This result is different from the report of Dang et al (2001) and Marta (2015). (Commendatore et al, 2015) showed that organochlorine bioaccumulation processes through bottom sediment resuspension were found in surface sediment and bivalve molluscs (29.4-206.0 ng/g dry weight); whereas imposex incidence was only $15 \%$ in the gastropod Pareuthria plumbea. Moreover, the presence of p,p'-DDT and the p,p'-DDE ratio likely reflect the high 
stability of the stock compounds and their isomer in the aquatic environment compared with other metabolites. The OCP compounds in bivalve molluses showed different patterns. This result may be due to different input pathways such as OCPs being incorporated into organisms directly from the water column's suspended particles while being transformed in sediments. According to these authors (Dang et al, 1998; Commendatore, 2015), the organochlorinated pollution was clearly related to the migration of contaminants and the ability to self-disintegrate pesticides by environmental factors such as: temperature, atmosphere, transport etc.

\section{Conclusion}

This study demonstrates the high accumulation levels of organochlorine pesticides in different species of bivalve molluscs cultured in the Sai Gon - Dong Nai estuary compared with Vietnam standard 10:2008/MONRE. Endosulfan was the most commonly found in three bivalve molluscs (4,591-27,831 $\mu \mathrm{g} / \mathrm{kg}$, average $14,144 \mu \mathrm{g} / \mathrm{kg}$ by wet weight) while DDTs $(6,124-16,662 \mu \mathrm{g} / \mathrm{kg}$, average $9,4565 \mu \mathrm{g} / \mathrm{kg}$ by wet weight) was the most popular OCPs in the fish ( $B$. sinensis) samples. In DDT group, the p,p'-DDT metabolite accounted for the largest percentage, reaching $50 \%$ of total DDTs. In $\mathrm{HCH}$ (Hexachlorocyclohexane) group, $\beta-\mathrm{HCH}$ isomer was predominant in almost samples. However, in order to have more consistent and scientific assessments, it is necessary to combine with the study of OCPs deposit in water, sediment and other aquatic parameters to limit the potential for bioaccumulation of the pesticides in these species.

\section{References}

[1] Anh MT, Chi DHL, Vinh NN, Loan TTC, Triet LM, Slooten KB, Tarradellas J (2003) Micropollutants in the sediment of the SaiGon-DongNai River: situation and ecological risks. Chimia, 57, 537-541.

[2] Canadian Cancer Society (2013) Cosmetic Pesticides. Information Brief. Available from: https://www.cancer.ca/ /media/cancer.ca/AB/get $\% 2$ 0involved/take\%20action/CosmeticPesticidesInformationBrief-AB.

[3] Cantor KP, Blair A, Everett G, Gibson R, Burmeister LF (1992) Pesticides and other agricultural risk factors for non-Hodgkin's lymphoma among men in Iowa and Minnesota. Cancer Res, 52, 2447-55.

[4] Circular No. 21/2013/MARD: The promulgating the list of pesticides permitted for use, limited use, forbidden to use and the additional list of plant varieties permitted for production and trading in Viet Nam.

[5] Circular No. 31/2015/MARD: Regulations on monitoring residues of toxic substances in animals and seafood products.

[6] Cohn B, Wolff M, Cirillo P, Sholtz R (2007) DDT and Breast Cancer in Young Women: New Data on the Significance of Age at Exposure. Environmental Health Perspectives, 115(10), 1410-1414.

[7] Hancock DB, Martin ER, Mayhew GM, Stajich JM,
Jewett R, Stacy MA, Scott BL, Vance JM, Scott WK (2008) Pesticide exposure and risk of Parkinson's disease: A family-based case-control study. BMC Neurology, 8(6). doi:10.1186/1471-2377-8-6

[8] Dang DN, Carvalho FP, Nguyen MA, Nguyen QT, Nguyen THY, Villeneuve JP, Cattini C (2001) Chlorinated pesticides and PCBs in sediments and molluscs from freshwater canals in the Hanoi region. Environmental Pollution, 112(3), 311-320.

[9] Dang DN, Nguyen MA, Nguyen CH, Luu VD, Carvalho FP, Villeneuve JP, Cattini C (1998) Organochlorine pesticides and PCBs in the Red River Delta, North Vietnam. Marine Pollution Bulletin, 36(9), 742-749.

[10] Nicol D (1969) The Number of Living Species of Molluscs. Systematic Zoology, 18(2), 251-254

[11] Hoang TD, Kunzmann A (2015) The Sediment Load and Deposition by River Discharge and Their Relation to Organochlorine Pesticides Pollutants in the Sediment Bottom of Nha Trang Bay, Vietnam. Ocean Sci. J, 50(2), 455-466.

[12] Darija K, Snježana HR, Zorana KG, Jere V (2008) Levels of Polychlorinated Biphenyls and Organochlorine pesticides in Mediterranean blue mussel from the Adriatic sea. Organohalogen Compounds, Volume 70, pp. 001243.

[13] Le Duc An (2015) Coastal Vietnam, structure and natural resources. Natural Science and Technology Publisher (in Vietnamese).

[14] Commendatore MG, Franco MA, Costa GP, Castro IB, Fillmann G, Bigatii G, Esteves JL, Nievas ML (2015) Butyltins, polyaromatic hydrocarbons, organochlorine pesticides, and polychlorinated biphenyls in sediments and bivalve mollusks in a mid-latitude environment from the patagonian coastal zone. Environmental Toxicology and Chemistry, 34(12), 27502763.

[15] Mathur V, Bhatnagar P, Sharma RG, Acharya V, Sexana R. (2002) Breast Cancer incidence and exposure to pesticides among young women originating from Jaipur. Environment International, 28, 331-336.

[16] Alavanja MCR, Ross MK, Bonner MR (2013) Increased Cancer Burden Among Pesticide Applicators and Others Due to Pesticide Exposure. J CLIN, 63, $120-142$.

[17] Minh NH, Someya M, Minh TB, Kunisue T, Watanabe M, Tanabe S, Viet PH, Tuyen BC (2004) Persistent organochlorine residues in human breast milk from Hanoi and Ho Chi Minh City, Vietnam: Contamination, accumulation kinetics, and risk assessment for infants. Environ Pollut, 129, 431-441.

[18] Mnif W, Hassine AIH, Bouaziz A, Bartegi A, Thomas O, Roig Bendo (2011) Effect of endocrine disruptor pesticides: a review. Int J Environ Res Public Health, 8, 2265-2203.

[19] Shreadah MA, Said TO,. Othman IM, Eiman M. I. Fathallah MEM (2012) Polychlorinated Biphenyls and Chlorinated Pesticides in Sediments along the 
Semi-Closed Areas of Alexandria, Egypt. Journal of Environmental Protection 3, 141-149.

[20] Nguyen HM, Tu BM, Iwata H, Kajiwara N, Kunisuem T, Takahashi S, Pham HV, Bui CT Tanabe S (2007) Persistent Organic Pollutants in Sediments from Sai Gon-Dong Nai River Basin, Vietnam: Levels and Temporal Trends. Arch. Environ. Contam. Toxicol, 52, 458-465.

[21] Nguyen HM, Tu BM, Kajiwara N, Kunisue T, Hisato Iwata, Pham HV, Nguyen PCT, Bui CT, Tanabe S (2006) Contamination by polybrominated diphenyl ethers and persistent organochlorines in catfish and feed from Mekong river delta, Vietnam. Environmental Toxicology and Chemistry, 25(10), 2700-2709.

[22] Nguyen VH Hoang TQD, Nguyen HP (2017) Metal speciation in sediment and bioaccumulation in Meretrix lyrata in the Tien Estuary in Vietnam. Environ Monit Assess, 189(6), 299.

[23] Pham MH, Zita S, Tu BM, Pham HV, Renaud FG (2011) Pesticide pollution in agricultural areas of
Northern Vietnam: Case study in Hoang Liet and Minh Dai communes. Environmental Pollution, 159, 3344-3350.

[24] Bretveld RW, Thomas CMG, Scheepers PTJ, Zielhuis AG, Roeleveld N (2006) Pesticide exposure: the hormonal function of the female reproductive system disrupted? Reproductive Biology and Endocrinology, 4, 30 .

[25] Costa-Böddeker S, Hoelzmann P, Le XT, Hoang DH, Hoang AN, Richter O, Schwalb A (2016) Ecological risk assessment of a coastal zone in Southern Vietnam: Spatial distribution and content of heavy metals in water and surface sediments of the Thi Vai Estuary and Can Gio. Marine Pollution Bulletin 114(2), 1141-1151.

[26] UNEP (2011) Stockholm Convention on Persistent Organic Pollutants.

[27] Vietnam standard 10:2008/MONRE: National technical regulation on coastal water quality. 